\title{
The Relationship of Spirituality Level with Motivation to Heal Critical Patients at Tgk Chik Hospital in Tiro Sigli
}

\author{
Risna $^{1}$, Muhammad Iqbal ${ }^{2}$ \\ ${ }^{1}$ STIKES Medika Nurul Islam, Sigli, Indonesia \\ ${ }^{2}$ Universitas Jabal Ghafur, Sigli, Indonesia \\ aisrisna250787@gmail.com,muhammadiqbal@unigha.ac.id
}

\begin{abstract}
Several studies have shown that low spirituality in critical patients results in reduced expectations, strength and motivation to face the critical conditions they face. The purpose of this study was to determine the relationship between spirituality level and motivation to recover in critical patients at Tgk Chik Hospital in Tiro Sigli. This type of research is descriptive research. The subjects of this study were 30 critical patients who were selected by accidental sampling. The variables in this study were spirituality as the independent variable and the dependent variable was the patient's motivation to recover. Data collection instruments in the study consisted of a demographic and characteristic data questionnaire, a Spirituality questionnaire and a patient recovery motivation questionnaire using the Acceptance Illness Scale (AIS). The relationship between spirituality and patient motivation to recover was analyzed using the Spearman Rank (Rho) test. The results showed that almost half (47.1\%) of critical patients had moderate spirituality and low spirituality (29\%); almost half (47.1\%) experienced moderate and high motivation to recover (32.1\%). There is a relationship between spirituality and motivation to heal patients $(p=0.002)$, where patients who have high spirituality have high motivation to recover.
\end{abstract}

\author{
Keywords \\ spirituality, motivation to heal critical \\ patients, Tgk Chik Hospital
}

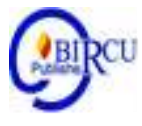

\section{Introduction}

Patients' spirituality in a health-care setting is the effect on their behavior and healthrelated decisions. The United States states $60 \%$ of people that religion is the most important influence in their daily life. People who are hospitalized or outpatient expresses a strong spiritual and religious approach. Of the 200 outpatients indicated that more than $91 \%$ believed in God, $81 \%$ used prayer, and $71 \%$ felt close to God. The survey results on critical patients at Tgk Chik Hospital in Tiro Sigli revealed that 99\% believed in God, $80 \%$ prayed daily, 95\% agreed that spirituality is as important as physical health. The need for the spiritual aspect is especially important during periods of illness, where when sick, a person's energy and spirituality will decrease. Therefore, the patient's spiritual needs need to be met (Potter \& Perry, 2005). Research conducted by Hodge et al (2011) on spiritual needs, in which patients revealed that spiritual need is the need for meaning, purpose and hope in life, its relationship with God. Most studies have shown that religious and spiritual involvement can promote far better health such as survival and health-related quality of life, as well as less exposure to anxiety, depression and suicide. Sujana, (2017) shows that patients really need spiritual fulfillment in their healing and restoration process. The impact of spiritual problems with patient satisfaction is something that absolutely must be fulfilled by every health service provider or hospital. Because patient satisfaction is the feeling of a person or society after comparing the results felt with expectations. Patients will feel satisfied if the results they feel 
exceed their expectations, if they are not fulfilled as expected, a feeling of disappointment or dissatisfaction will arise if the results they feel are not in accordance with their own expectations (Winarti, 2016) if not fulfilled according to his expectations, a feeling of disappointment or dissatisfaction will arise if the results he feels are not in accordance with his own expectations.

Based on the researcher's experience when practicing in intensive care, there were some critical patients who experienced spiritual problems. The spiritual problems they experience include feeling anxious, worried, angry and complaining about their current condition and the belief that they will recover is very minimal. Critical patients who are treated in intensive care rooms do not get closer to God. This happens because the presence of nurses who are too focused on physical problems, as well as from the hospital who do not facilitate meeting the spiritual needs of critical patients. 5 critical patients interviewed by the researcher complained that they were afraid that they would not be able to recover or recover from their illness so that thoughts could affect their recovery.

Based on the results of the study conducted by researchers through interviews with the education and training section RSUD Tgk Chik at Tiro Sigli The data obtained were that in the intensive care room there were activities to fulfill the spiritual needs of patients including worship, helping patients pray for Muslim patients, providing motivation, communicating with God by praying accompanied by a facilitator. The facilitators referred to here are spiritual nurses and guides (Rohis).

Based on this phenomenon, the researcher wants to conduct research to determine the relationship between the level of spirituality and the motivation to recover in critical patients who are treated at RSUD Tgk Chik at Tiro Sigli.

\section{Review of Literature}

\subsection{Spirituality}

Spirituality is belief in relation to God Almighty and Creator. Spiritual needs are the need to find meaning and purpose in life, the need to love and be loved and a sense of attachment and the need to give forgiveness and forgiveness(Wulan, 2011). According to Bambang (2010), the spiritual definition of each individual is influenced by culture, development, life experience, beliefs and ideas about life itself. Spirituality also provides a feeling related to intrapersonal (relationships between oneself), interpersonal (relationships between other people and the environment) and transpersonal (relationships that cannot be seen, namely a relationship with divinity which is the highest power. Spiritual needs are a basic human need that must be fulfilled.

Spiritual means a belief approach, hope and belief in God and the need to practice the religion followed, the need to be loved and forgiven by God which is wholly owned and must be maintained by someone at any time in order to obtain help, calm, safety, strength, comfort and healing. (Bambang, 2010). Spiritual needs also aim to maintain or restore faith and to gain forgiveness or forgiveness, to love, to have a trusting relationship with God. Spiritual needs as part of human needs as a whole can only be met if the nurse is equipped with the ability to provide nursing care by paying attention to the spiritual aspects of the client as part of the patient's holistic needs as a complete and unique being. Sugianto (2020) another form of spiritual support in addition to praying is to support other people to worship and carry out religious rituals. One form of compassion from participants is forgiveness. Apart from that, there is sacrifice and serve. The form of sacrifice and serve is giving in, giving priority to the interests of others over oneself, devoting life for sake of servicing others. Whereas acts of compassion include in other categories consist of respect, acceptance without discrimination, 
respect for different opinions, making the parents proud of, being patient in facing the bad characters of others, and being friendly to others. as easy as turning the palm of the hand, but it requires a mental and spiritual calling in living it (Imran Sinaga, 2020).

\subsection{Patient's Motivation to Recover}

According to Chaplin (in Iryani 2007) states that recovery is the return of a person to a normal condition after suffering from an illness, mental illness, or injury. Motivation to heal is a factor that encourages people to act in certain ways in order to obtain healing. Wulandari (2020) states that motivation can describe the processes that can bring up and encourage behavior, provide direction and purpose of behavior and can determine whether or not good in achieving goals. Thus, it can be said that motivation to recover is basically a mental condition that encourages action (action or activity) and provides strength (energy) which leads to the achievement of recovery. The motivation to recover has decreased in patients diagnosed with chronic disease (Maria et al., 2004). Motivation that has grown can be the motor and drive to achieve healing (Ryan \& Deci 2000).

Bice, Ball, and Mc Claran in Arsani (2020) define motivation as a psychological construct that directs a person towards achieving goals and considers the psychological forces that are used to reinforce actions. Besides motivation as one of the driving forces for someone to realize their aspirations, motivation is also a student psychological factor that greatly influences learning activities. According to Cortes, et al. (2017) motivation is at the heart of many of the most interesting problems of sport as a result of the development of the social environment such as competition, persistence, learning and performance. Cortes, et al. (2017) also added that there are two types of motivation, namely intrinsic motivation and extrinsic motivation.

The motivational aspects of healing according to Conger (1997) in (Ryan \& Deci, 2000) are as follows:

a. Have a Positive Attitude

This encourages strong individual self-confidence, high self-planning, and is always optimistic in dealing with something.

- Oriented to goal achievement

This aspect shows that motivation provides a purposeful orientation of behavior that is directed (in Tuberculosis, Health and Health Facilities, 2016)

- The forces that drive the individual

This shows that the emergence of strength will encourage someone to do something. This power comes from within a person, the environment around and belief in natural power (God).

Some of the thoughts of Levine (2011) regarding motivation are as follows:

1. Motivation is essential for healing. If maintained consistently it can promote recovery and healing

2. Motivation is often the most influential factor in healing

3. Motivation is at the heart of healing and healing.

\subsection{Critical Patients}

Critical patients are patients who are physiologically unstable, so they experience a complex hypermetabolic response to trauma, pain experienced which can change the body's metabolism, hormonal, immunological and nutritional homeostasis (Menerez, 2012). Patients who enter the ICU care room generally vary, namely elective patients after major surgery, emergency patients due to major trauma, stress due to trauma, injury, surgery, sepsis or respiratory failure. This situation can lead to increased metabolism and catabolism which can lead to malnutrition (Menerez, 2012). Critical patients in the ICU are required to undergo bed 
rest. Stabilization of hemodynamic conditions, installation of various monitoring tools and life support, Postoperative patients and decreased status of consciousness, both physiological and sedation programs, are challenges for nurses to mobilize critical patients. The complexity of the therapy program and critical patient monitoring requires nurses to be able to continue to focus on stabilizing the respiratory, circulatory and other physiological states in order to sustain the patient's life. This causes the mobilization to be sometimes overlooked by nurses (Menerez, 2012).

\section{Research Methods}

The type of research used is non-experimental quantitative research with a correlational method, which is to see the description of the degree of relationship that exists between spirituality and spirituality variables.Motivation to Heal Critical Patients at Tgk Chik Hospital in Tiro Sigli. The populations in this study were all critical patients with a sample size of 31 clients who were selected by accidental sampling. The variables in this study were spirituality as the independent variable and the dependent variable was critical patient recovery motivation. The data collection instrument in the study consisted of a demographic and characteristic data questionnaire, a Spirituality questionnaire and a Critical Patient Healing Motivation questionnaire. To find out the spiritual orientation, the researcher adopted Ellison's Spiritual Well Being Scale which was translated into Indonesian. The questionnaire used used a Likert scale, where the answers were arranged on a six-scale continuum, with categories strongly disagree, quite disagree, disagree, agree, sufficient agree, totally agree. The categories of spiritual assessment are low spiritual (21-60), moderate spiritual (61-100), and high spiritual 101-121. Measurement of patient's motivation to recover variables used the Acceptance of Illness Scale questionnaire by BJ Felton, TA Reverson and GA Hinrichen which was adopted from Z. Juczynski. Scoring on a self-acceptance scale based on ratings on a Likert scale. The assessment categories on the Acceptance Illness Scale are low (7-18), moderate 19-28, high (30-40) (Elzbieta, Cipora, et al, 2017). To determine the relationship between spirituality and motivation to heal critical patients, the Spearman Rank statistical test was performed with a predetermined degree of significance or significance, namely $\alpha=5 \%$.

\section{Discussion}

The results of cross tabulation between spirituality and motivation to recover patients, critical patients showed that most $(56.3 \%)$ patients with low spirituality had low motivation to recover. Most (65.2\%) patients with moderate spirituality had moderate motivation to recover. Meanwhile, almost all $(86.6 \%)$ patients with high spirituality had high motivation to recover.

Table 1. Tabulation of Motivation to Heal Patients with Spirituality

Spiritual

Patient's motivation

Total

\begin{tabular}{|c|c|c|c|c|c|c|c|}
\hline & & Low & & Moderate & & High & \\
\hline & $\mathrm{f}$ & $\%$ & $\mathrm{f}$ & $\%$ & $\mathrm{f}$ & $\%$ & $\mathrm{~F} \%$ \\
\hline Low & 4 & 53.2 & 4 & 46.1 & 1 & 1 & 10 \\
\hline Moderate & 2 & 6.9 & 10 & 63.9 & 3 & 27.5 & 13 \\
\hline High & 1 & 1 & 1 & 13.9 & 7 & 84.9 & 6 \\
\hline Total & 7 & & $\begin{array}{l}15 \\
811\end{array}$ & $002 ; \alpha=$ & 11 & & 29 \\
\hline
\end{tabular}


This healing processinterpreted as a process of acceptance of the disease so that the patient feels at ease in his life. This is because of the optimism in respondents which is influenced by their self-awareness of the transcendent dimension (God, Allah SWT) in their life. According to Harlianty and Ediati (2016), overall critical patients consider spirituality to be important for their lives, it can help patients coping with their illness and are able to deal with psychological distress due to their disease conditions.

Health workers are expected to provide motivation to breast cancer clients undergoing chemotherapy so that they can accept themselves through increasing spirituality by accustoming clients to pray for healing from God, giving time for clients to perform worship. By increasing spirituality, cancer clients can accept their disease conditions well and be able to undergo treatment procedures and comply with the treatment process they are undergoing.

\section{Conclusion}

Based on the results of research on critical patients RSUD Tgk Chik at Tiro Sigli, it can be concluded that almost half $(47.1 \%)$ of critical patients have moderate spirituality and low spirituality (29\%); almost half (47.1\%) experienced moderate and high motivation to recover $(32.1 \%)$. There is a relationship between spirituality and motivation to heal patients, where patients who have high spirituality have high motivation to recover.

\section{References}

Arsani, et.al. (2020). Differences in Motivational Orientation in Physical Education in terms of Gender Differences. Budapest International Research and Critics in Linguistics and Education (BirLE) Journal Vol 3 (3): 1428-1434.

Bambang. 2010 . Pemahaman Perawat dalam Pemenuhan Kebutuhan Spiritual pada Lansia.http://eprints.undip.ac.id/10/28/8/INNANYAH.pdf.Diakses pada hari Selasa $11 / 2 / 2014$

Cipora, Elzbieta,dkk. (2017). Acceptance of Ilness by Women Breast Cancer. Annals of Agricultural and Environmental Medicine. Tersedia di:

http://www.aaem.pl/Acceptance-ofillness-by-women-with-breast cancer, 75876, 0,2. html.[diakses 1 Maret 2018].

Harlianty dan Ediati.(2016).Hubungan Antara Kesejahteraan Spiritual dengan Kepuasan Hidup Pada Pasien Kanker Payudara di RSUD Dr.H Abdul Moeloek Provinsi Lampung. Skripsi, Fakultas Psikologi Universitas Diponegoro. Tersedia di: https://ejournal3.undip.ac.id/index.ph p/empati/article/view/. [Diakses 12 Juli 2018]

Hodge et al (2011). Pemenuhan Kebutuhan Spiritual Pasien Di Ruang Rawat ICU Rumah Sakit Umum Daerah Haji Makassar, (Online).

Maria, E., Reiche, V., Odebrecht, S., Nunes, V., \& Morimoto, H. K. (2004). Review Stress , depression, the immune system, and cancer, 5(October), 617-625.

Menerez, Fernanda de Souza., Heitor Pons Leite., Paulo Cesar Koch Nogueira. 2011. Malnutrition as An Independent Predictor Of Clinical Outcome In Critically Ill Children. Journal of Nutrition 28 (2012) 267-270. Diakses tanggal 4 Juli 2014 pukul 12.24 WIB. http://search.proquest.com.

Perry \& Potter. (2006). Fundamental of Nursing Fundamental Keperawatan. Buku 1 edisi 7. Jakarta: Salemba Medika.

Sugianto, M. (2020). The Birth of Compassion. Budapest International Research and Critics Institute-Journal (BIRCI-Journal) Vol 3 (2): 777-790.

Sujana. (2017). Kebutuhan Spiritual Keluarga Dengan Anak Penderita Penyakit Kronis. (Online). 
Utomo, M.R., Hasruddin, and Murad, A. (2020). Influence of Problem Based Learning Models (PBL) and Learning Motivation to Learn Outcomes and Student's Critical Thinking Skills Themes of Caring for Life in Class IV Primary School No 026609 Pujidadi Binjai. Budapest International Research and Critics in Linguistics and Education (BirLE) Journal Vol 3 (4): 1634-1643.

Winarti. (2016), Pengaruh Penerapan Asuhan Keperawatan Spiritual Terhadap Kepuasan Pasien Di Rumah Sakit Islam Sultan Agung Semarang. (Online).

Wulan, Kencana. 2011. Pengantar Etika Keperawatan . Jakarta : Prestasi Pustakarya

Wulandari, U.N., Ansari, K., and Hadi, W. (2020). The Effect of Cooperative Learning Models and Learning Motivation towards the Skills of Reading Students in Public Elementary School 101883 Tanjung Morawa Sub-district. Budapest International Research and Critics in Linguistics and Education (BirLE) Journal Vol 3 (2): 12091219. 